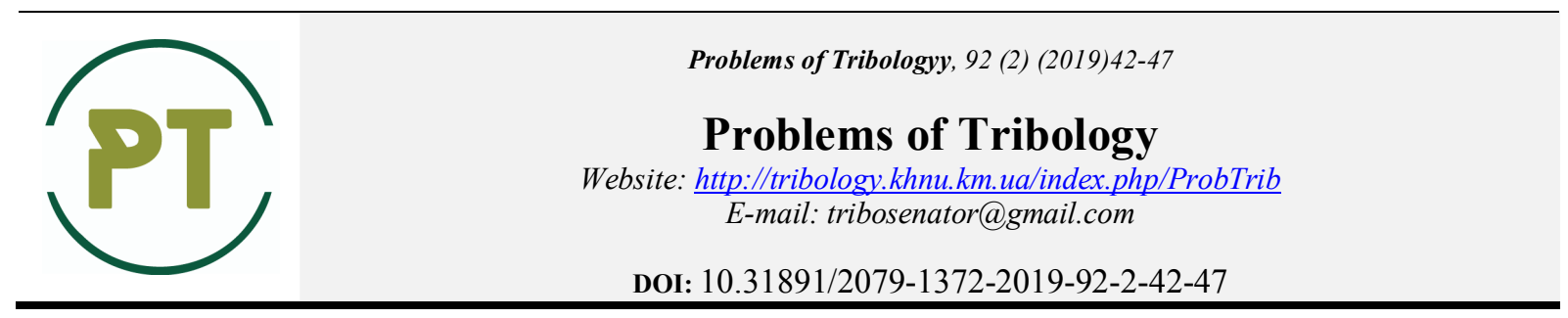

\title{
Formation of the characteristics of the energy state in the local contact of the processing and tool materials in the cutting process
}

\author{
V.G. Buryak ${ }^{1 *}$ A.V. Buryak ${ }^{2}$, V.V. Buryak ${ }^{2}$ \\ ${ }^{1}$ Khmelnitsky Regional Institute of Postgraduate Pedagogical Education, \\ ${ }^{2}$ Khmelnitsky National University, Ukraine \\ *E-mail: viktorburyak1955@gmail.com
}

\begin{abstract}
The formation of characteristics of the energy state in the local contact of machined and tool materials in the cutting process is performed. The adoption of a model of the choice of unit microniveness in the form of a straight truncated cone is substantiated. The rate of deformation of the machined material on of unit microniveness is determined. The probability of the presence of acoustic oscillation and wave processes that occur in the conventional shear plane during the cutting process is shown. The dependence of the magnitude of unit microniveness area on the roughness parameters is established. Analyzing the dimensions of microniveness, and also taking into account the calculated data of the autocorrelation function of the structural and energy state of the working surfaces of the cutting plates, which in microniveness there is a certain amount of grain of the solid base of the material of the cutting plates. The functional dependences of the conditional number of grains on the size of roughness parameters as well as on the average grain size are established. The obtained research results are the initial data when using the methodology of performance evaluation of cutting tools by analyzing the acoustic characteristics of the energy state of processing and instrumental materials using the differential equation of cause and effect relationship.
\end{abstract}

Key words: cutting machining, microstructure of working surfaces of tools, autocorrelation function, acoustic properties of materials, causal relationship, wear.

\section{Introduction}

Consideration of the local interaction of processing and instrumental materials, as contacting rough surfaces is becoming increasingly relevant. A set of protrusions and depressions on the work surfaces of the tool causes the uneven distribution of localized pressures, which vary greatly in size from the nominal pressure. Generalization of parameters is performed using the theory of causation [1-4]. To determine the characteristics of the structural and energy state of the working surfaces of composite cutting plates, an autocorrelation function is used. The use of research results allows to carry out the appropriate substantiation in the design of optical electronic devices for non-destructive quality control of composite cutting plates and in predicting the structural and energy state of the working surfaces of the plates and ensuring the guaranteed values of wear resistance of the tool.

\section{The purpose and task statement}

In order to use the differential equation of causation [1-4] an analysis of the energy state characteristics in the local contact of processing and tool materials in the process of cutting is performed. Taking into account the direct connection of the work of friction with localized pressure over time, there was a need to determine the change in the characteristics of the microstructural energy state of the instrumental material on separate sections of the working surfaces of the tool. Therefore, in analyzing the reasons for reducing the efficiency of tools, it is important to assess the state of their working surfaces. It is proved that one of the reasons for the loss of efficiency of composite instruments is the accumulation of stresses in the microstructure of the tool material due to the continuous action of acoustic vibrational and wave processes. In the further development of the research, in the main publications [3-6], the problems of the assessment of the performance of the composite tool by analyzing the acoustic characteristics of the energy state of the cutting material were substantiated. 


\section{Presentation of research materials}

In accordance with the scheme of contacting of processing and instrumental materials, the model of unit microniveness (inequality) in the form of a straight truncated cone is adopted (Fig. 1). The lawfulness of adopting such a model is based on the analysis of the structural and energy state of the working surfaces of the cutting plates $[7,8]$. Analysis of the values of standard parameters of roughness of working surfaces for various instrumental materials showed the validity of the following inequality:

$$
S m>R a,
$$

where $S m$ - the step of inequalities along the middle line;

$R a$ - average arithmetic deviation of profile of inequalities in the middle line.

The given fact causes the formation of small angles of inclination of the inequalities: $\gamma_{n}=1 \ldots 2^{\circ}$. Condi-

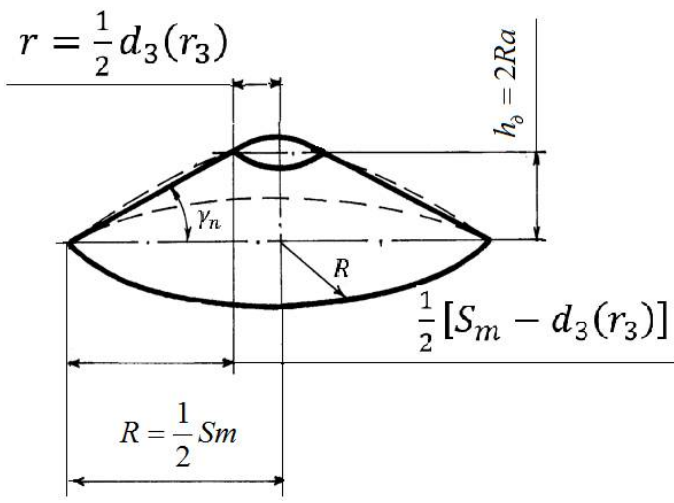

Fig. 1. Model of the geometric form of unit inequality tion (1) gives the basis for replacing the radius side surface of the inequalities in a straight line. Also, with the use of optical electronic devices, by analyzing profilograms of rough surfaces of cutting plates [8] the presence of the microscopic grains of the solid of the tool material (the size of the single grain $d_{3}\left(r_{3}\right)$ is shown in Fig. 1), which led to the need to select the model of inequality in the form of a straight truncated cone. In addition, according to the accepted scheme of contacting, it is possible to analyze the more powerful nature of changes in the characteristics of the energy state by the presence of transitional regions, which results in a higher intensity of acoustic vibrational and wave processes in comparison with the spherical model of unit inequality.

At this stage, consideration of the principle approach to determining the change in the acoustic characteristics of the energy state, takes the value of the deformation $h_{\partial}$ equal to twice the value of the mean arithmetic deviation of the profile of the inequalities along the midline $R a$, ie $h_{\partial}=2 \cdot R a$. In the case of considering the characteristics of the energy state for inequality, the rate of chip formation $V_{C}$ is determined by the following formula:

$$
V_{C}=\frac{V}{K_{l}}
$$

where $V$ - cutting speed;

$K_{l}$ - the coefficient of shrinkage chips during the cutting process.

Taking into account the conditions of the modeling (2) adopted above, by means of mathematical transformations (using reference data [9]), the formula for determining the rate of deformation of the processed material on the unit inequality in the process of mechanical processing has the following form:

$$
\dot{\varepsilon}_{H}=\frac{V}{K_{l}} \cdot \frac{\sqrt{16 R a^{2}+\left[S m-d_{3}\left(r_{3}\right)\right]^{2}}}{2 R a\left[S m-d_{3}\left(r_{3}\right)\right]},
$$

where $d_{3}\left(r_{3}\right)$ - grain size of instrumental material (determined by the statistical method [7]).

Calculations of the deformation velocity $\dot{\varepsilon}_{H}$ were carried out in a wide range of changes in cutting speed $V=(0,6 \ldots 6,0) \mathrm{m} / \mathrm{s}$ and shrinkage coefficient $K_{l}=1,2 \ldots 2,0$. The results of the calculations of the deformation velocity according to the formula (3) are as follows: $\dot{\varepsilon}_{H}=\left(0,8 \cdot 10^{6} \ldots 2,67 \cdot 10^{6}\right) 1 / \mathrm{s}$, which allows us to assert the probability of overlaying acoustic oscillation and wave processes that pass in the conventional shear plane with a deformation $\dot{\varepsilon}=\left(1 \cdot 10^{3} \ldots 1 \cdot 10^{6}\right) 1 / \mathrm{s}[10]$ and in unit inequalities. 
As shown above, the working surfaces of the cutting plates have a heterogeneous microstructure, which is determined by the random nature of the distribution of the solid base (grain) and material. However, the formation of an isotropic relief of inequalities allows, within the limits of a certain error, to systematize the structural energy state of the working part of the tool, to consider separate areas of the contact of processing and instrumental materials on a local scale: as infinitely small contact areas, and within the size of individual grains, groups of grains, and unit inequalities. According to the values of the roughness parameters $R a$ and $S m$, the fact that the angles of inclination of the unit inequality are determined within the values of $1 \ldots 2^{\circ}$ is determined. In order to describe the parameters of the local contact on the basis of the above results of the study of the working surfaces of the tool, a model of the geometric form of unit inequality in the form of a straight truncated cone is adopted (Fig. 1).

A straight truncated cone has a radius of the base $R$ which is equal to half the profile step inequality on the middle line $S m$ and the radius at the vertex $r$, which functionally depends on the passport data of the size of the grain $d_{3}\left(r_{3}\right)$, which acts on the microstructure of the tool material. The cone height $h_{\partial}$ is equal to the double value of the arithmetic mean deviation of the points of the surface $R a$. Taking into account the given simulation conditions, the value of the area $S r$ of the unit inequality is written in the form of the following dependence:

$$
S r=\pi \cdot\left\{\sqrt{\frac{1}{\sqrt{2^{5}}}} \cdot\left[S m-d_{3}\left(r_{3}\right)\right]^{2}+R a^{2} \cdot\left[S m+d_{3}\left(r_{3}\right)\right]+\frac{1}{4} \cdot\left[d_{3}\left(r_{3}\right)\right]^{2}\right\} .
$$

Thanks to the application of formula (4), the dependence of the size of the area $S r$ of the unit inequality on the roughness parameters $R a$ and $S m$ (Fig. 2) is established. The increase in the area is determined by increasing the roughness parameters $R a$ and $S m$. The more intense growth of the area $S r$ causes the profile of the inequalities along the middle line $\mathrm{Sm}$.

The results of the aforementioned analysis of the size of the inequalities, as well as the consideration of

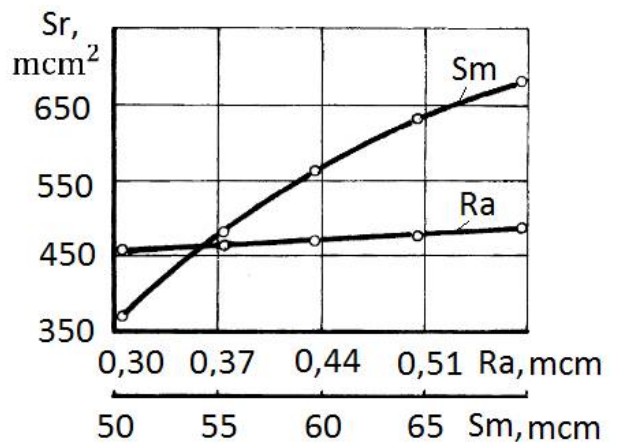
the design data of the autocorrelation function of the structural and energy state of the working surfaces of the device [1], showed that inequality has a certain number of superhard grains. Using the passport data on the dimensions of superhard materials (SHM) and surface roughness parameters $R a$ and $S m$, we can draw conclusions about the composition of the inequality. Grains are separated by binding material. Significant loads of mechanical and thermal energy are concentrated on inequality. Therefore, the calculation of the magnitude of inequality is very important. This is especially true when performing an analysis of changes in the energy state of instrumental material.

For a comparative assessment of the efficiency of

Fig. 2 . The dependence of the area of inequality $S r$ on the roughness parameters $R a$ and $S m$ tools adopted a characteristic of the relative number of grains contained in the volume of unit inequality. Obviously, depending on a given number of grains that are inequality, physical properties, the activity of internal friction in the material of the plate during the cutting will be different. Taking into account the parameters of the inequality, the conditional number of grains $n_{y}$ in the volume of the unit inequality is calculated by the following dependence:

$$
n_{\mathrm{y}}=\frac{n \cdot V_{A} \cdot \rho}{m_{K}},
$$

where $n$ - number of grains per unit of mass;

$V_{A}$ - the volume occupying grain in the unit inequality;

$\rho$ - density of grain material;

$m_{K}$ - weight of one carat for grains with SHM.

The number of SHM grains in one carat with an average grain diameter $d_{3}$ is determined by the formula V.M. Bakula (formula valid in a wide range of resizing $d_{3}$ : 


$$
n=2,83 \cdot 10^{11} d_{3}^{-3}
$$

where $d_{3}$ - the average diameter of the grain SHM, mcm.

The mass percent concentration of grains in the cutting layer is determined by the passport data on the plate. Then, the volume occupying grain in unit inequality, is determined by the following formula:

$$
V_{A}=V \cdot O \text {, }
$$

where $V$ - the volume of unit inequality;

$O$. - mass percentage grains in the cutting layer of the plates.

In accordance with the accepted model of the geometric form of unit inequality on the working surface of the tool (Fig. 1), the formula for determining the volume $V$ is as follows (the original formula for determining the volume of a straight truncated cone is taken with the reference [11]):

$$
V=8 \cdot \pi \cdot R a \cdot\left\{\operatorname{Sm} \cdot\left[\operatorname{Sm}+d_{3}\left(r_{3}\right)\right]+\left[d_{3}\left(r_{3}\right)\right]^{2}\right\} / 3
$$

Also, as already noted above, grains in the volume of inequalities are partially in the following ratio:

$$
K_{r}=\frac{d_{3}}{2 \cdot R a}
$$

then, the number of grains, which are partly in the volume of inequality, is determined by:

$$
n_{r}=K_{r} n_{y}
$$

The calculations of the amount of grains $n_{y}$ are made using formulas (4) and (5) under the conditions of changing the roughness parameters of the working surfaces of the cutting discs of the alum [12]: $R a=(0,312 \ldots 0,562) \quad \mathrm{mcm} ; \quad S m=(48 \ldots 72) \quad \mathrm{mcm}$ and the size of the single grain $d_{3}\left(r_{3}\right)=(0,5 \ldots 0,7) \mathrm{mcm}$. As a result of the calculations, the number of grains partly in the volume of the microstructure of the unit inequality is $-n_{y}=(272 \ldots 756)$ pieces of grain SHM. The dependence of the conditional number of grains on the magnitude of the roughness parameters $R a$ and $S m$ illustrates Fig. 3. The obtained results of calculations confirm the earlier assumption that the unit inequality of rough surfaces is a set of grains. It is established that none of the grains is found to have a complete initial size in the volume of the microstructure. The functional dependence of the number of grains $n_{y}$ on their average size $d_{3}$ is shown in Fig. 4. Uniform grains, also, form a microrelief on the surface of the basic inequality with much smaller values $R a$ and Sm.

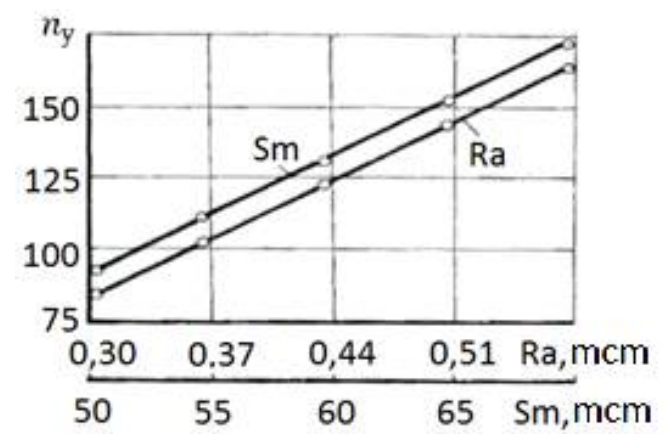

Fig. 3. Dependence of the number of grains $n_{y}$ on the roughness parameters $R a$ and $S m$ )

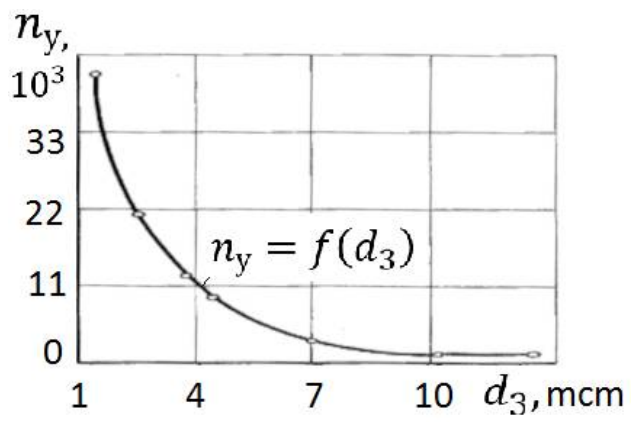

Fig. 4. Dependence of the number of grains $n_{y}$ from average size $d_{3}$ 
A more detailed analysis of the qualitative and quantitative characteristics of the influence of the parameters of inequality on the values $n_{y}$ and $S r$ must be performed on specific data on the composition of the instrumental material. In addition to the above calculations, it was also established that by simulating the geometric form of the unit inequality on the working surface of the tool of the adopted model of inequality in the form of a straight truncated cone $n_{y}$ and in the form of the half-sphere $n_{r}$, there are slight differences in the values of the number of grains $n_{y}$ and $n_{r}$ ( such that they do not exceed 1\%). This fact is due to the presence of conditions (1) and, as a consequence, the formation of small values of the angles of inclination of the inequalities constituting $1 \ldots 2^{\circ}$.

The number of grains on the surface of the unit inequality leads to a change in the conditions of contact between the processing and tool materials. This characteristic is important for the evaluation of the characteristics of the microstructural energy state of the tool material during the machining process

\section{Conclusions}

The formation of characteristics of the energy state in the local contact of machined and tool materials in the cutting process is performed. According to the values of the roughness parameters $R a$ and $S m$, the fact that the angles of inclination of the unit inequality are determined within the values of $1 \ldots 2^{\circ}$ is determined. The adoption of the model of unit inequality on the surface of the cutting plate in the form of a straight truncated cone is substantiated. According to the analysis of the results of calculations of the deformation velocity in the cutting process, the assertion about the probability of overlapping of acoustic oscillation and wave processes, which pass in the conditional shear plane and in unit inequalities, is grounded. The dependence of the value of the area $S r$ of the unit inequality on the roughness parameters $R a$ and $S m$ is established. The increase in the area is determined by increasing the roughness parameters $R a$ and $S m$. The more intense growth of the area $S r$ causes the profile of the inequalities along the middle line $S m$. According to the results of the dimensional analysis of inequalities located on the working surfaces of the tool, and also taking into account the calculated data of the autocorrelation function of the structural and energy state of the working surfaces of the cutting plates, it is established that in the volume and on the surface of the unit inequality there is a certain number of grains of the solid base of the cutting material plates As a result of the calculations, the number of grains partly in the volume of the microstructure of the unit inequality is $-n_{y}=(272 \ldots 756)$ grains. The functional dependences of the conditional number of grains on the size of roughness parameters as well as on the average grain size are established.

The obtained research results are the initial data when using the methodology of performance evaluation of cutting tools by analyzing the acoustic characteristics of the energy state of processing and instrumental materials using the differential equation of cause and effect relationship.

\section{References}

1. Buryak V.G., Buryak V.V., Drapak L.S., Buryak A.V. Autocorrelation function of model of image of working surfaces of composite cutting plates // Problems of tribology. - 2019. - № 1. - S.48-51.

2. Buryak V.G., Buryak V.V., Drapak L.S., Buryak A.V. Analiz harakteristik mikrostrukturi poverhon' kompozicijnih rizhuchih plastin // Problemi tribologiï. - 2018. - № 3. - S. 11-16.

3. Buryak V.G. Ocinka pracezdatnosti instrumentiv na osnovi analizu energetichnogo stanu obrobnih i instrumental'nih materialiv // Visnik tekhnologichnogo universitetu Podillya, seriya 1 "Tekhnichni nauki". 1997. - №1. - S. 51-54.

4. Buryak V.G. Ocinka pracezdatnosti kompozicijnih instrumentiv za analizom akustichnih harakteristik energetichnogo stanu instrumental'nogo materialu // Vimiryuval'na ta obchislyuval'na tekhnika v tekhnologichnih procesah. - 1998. - №1. - S. 49-56.

5. Buryak V.G., Rumbeshta V.O. Ocinka pracezdatnosti instrumentiv na osnovi analizu energetichnogo stanu instrumental'nih materialiv // Praci Mizhnar. Konf. "Progresivna tekhnika i tekhnologiya mashinobuduvannya, priladobuduvannya i zvaryuval'nogo virobnictva" (KIÏV 98). - Tom II. - Kï̈v: NTUU "KPI". - 1998. - S. 288-290.

6. Buryak V.G. Teoretichnij analiz kontrolyuyuchih i vimiryuval'nih harakteristik energetichnogo stanu obrobnih i instrumental'nih materialiv $\mathrm{u}$ mekhanoobrobci // Vimiryuval'na ta obchislyuval'na tekhnika $\mathrm{V}$ tekhnologichnih procesah. - 1997. - №1. - S. 36-42.

7. Buryak V.G., Maslov V.P., Miheenko L.A. Statisticheskij metod ocenki rezhushchih svojstv instrumenta // Stanki i instrument. - 1990. - №7. - S. 22-23.

8. Ocenka rezhushchih svojstv instrumentov statisticheskimi metodami / Buryak V.G., Maslov V.P., Miheenko L.A. - Hmel'nickij, 1988. - 15s. - Rus. - Dep. v UkrNIINTI 24.01.89, №374 - Uk 89. 
9. Spravochnik po matematike dlya inzhenerov i uchashchihsya vtuzov /Bronshtejn I.N., Semendyaev K.A. - M.: Nauka, 1981. - 718 s.

10. Bobrov V.F. Osnovy teorii rezaniya metallov. - M.: Mashinostroenie, 1975. - 344 s.

11. Frejdental' A., Gejringer H. Matematicheskie teorii neuprugoj sploshnoj Sredy. - M.: GIFML, 1962. $432 \mathrm{~s}$.

12. Vereshchagin L.F., Semerchan A.A., Gankevich T.T. i dr. Almet - almaznyj kompaktnyj material // Sinteticheskie almazy. - 1979. - Vyp.1. - S. 3-5.

Буряк В.Г., Буряк А.В., Буряк В.В. Формування характеристик енергетичного стану в локальному контакті обробного і інструментального матеріалів в процесі різання

Виконано формування характеристик енергетичного стану в локальному контакті оброблюваних і інструментальних матеріалів в процесі різання. Обгрунтовано прийняття моделі вибору одиничної мікронерівності у вигляді прямого усіченого конуса. Визначено швидкість деформації оброблюваного матеріалу на одиничній мікронерівності. Показана ймовірність наявності акустичних коливальних i хвильових процесів, які відбуваються в умовні площині зсуву в процесі різання. Встановлена залежність величини одиничної мікронерівності від параметрів шорсткості. Аналізуючи розміри мікронерівності, а також з урахуванням розрахункових даних автокореляційної функції структурного і енергетичного стану робочих поверхонь ріжучих пластин, у мікронерівності існує певна кількість зерна твердої основи матеріалу ріжучих пластин. Встановлені функціональні залежності умовного числа зерен від розміру параметрів шорсткості, а також від середнього розміру зерна. Отримані результати досліджень $\epsilon$ вихідними даними при використанні методології оцінки ефективності ріжучих інструментів шляхом аналізу акустичних характеристик енергетичного стану обробних та інструментальних матеріалів 3 використанням диференціального рівняння причинно-наслідкових зв'язків.

Ключові слова: оброблення різанням, мікроструктура робочих поверхонь інструментів, автокореляційна функція, акустичні властивості матеріалів, причинно-наслідковий зв’язок, знос. 